\title{
Long-term changes in precipitation phase in Czechia
}

\author{
MARTIN HYNČICA ${ }^{1,2}$, RADAN HUTH ${ }^{1,3}$
}

${ }^{1}$ Charles University, Faculty of Science, Department of Physical Geography and Geoecology, Prague, Czechia; e-mail: martin.hyncica@natur.cuni.cz

${ }^{2}$ Czech Hydrometeorological Institute, Regional Office, Ústí nad Labem, Czechia

${ }^{3}$ Czech Academy of Sciences, Institute of Atmospheric Physics, Prague, Czechia; e-mail: huth@ ufa.cas.cz

ABSTRACT Long-term changes in precipitation phase are investigated at ten stations in Czechia. Trends are calculated from 1983 to 2018 for the period between November and April. Daily SYNOP reports and daily precipitation totals are used at every station, where number and occurrence of specific codes in SYNOP report determine daily precipitation totals as solid, combined (which represents, to a large extent, category of mixed precipitation), or liquid. Thereafter, it is possible to calculate trends of all precipitation phases as well as the proportion of solid to total precipitation (S/P; in \%). The average S/P trend over all Czech stations is significantly negative $\left(-0.60 \% \cdot\right.$ year $\left.^{-1}\right)$ and accompanied by a sharp decrease in solid precipitation $\left(-1.66 \mathrm{~mm} \cdot\right.$ year $\left.^{-1}\right)$ and an increase in combined precipitation $\left(1.50 \mathrm{~mm} \cdot\right.$ year $\left.^{-1}\right)$. Thus, our results show a shift of precipitation phase from solid to combined. Because of the dependence of S/P on air temperature, we suppose that the current $\mathrm{S} / \mathrm{P}$ decline is a manifestation of rising air temperatures in the past decades.

KEY WORDS precipitation phase - precipitation - trends - air temperature - Czechia

HYNČICA, M., HUTH, R. (2019): Long-term changes in precipitation phase in Czechia. Geografie, $124,1,41-55$.

Received June 2018, accepted February 2019.

C Česká geografická společnost, z. s., 2019 


\section{Introduction}

Changes in precipitation phase, which basically correspond to changes in solid, mixed and liquid proportion in precipitation totals, form an important aspect of recent climate change. Rising air temperature typically results in an increase in liquid and decrease in solid precipitation, while trends of mixed precipitation are expected to be either positive (i.e. air temperature is more frequently close to zero now than in the past) or negative (i.e. air temperature is high above zero now, thus nearly all precipitation is liquid). Long-term changes in precipitation phase are often analysed in terms of the trend of proportion of solid to total precipitation (S/P; in \%). Warming of climate causes air temperature to be more frequently close (or above) zero, which subsequently leads to the decrease of S/P and vice versa.

The most vulnerable regions facing the decrease of S/P cover lower mountainous areas, mild and also boreal zones with warmer climate where air temperature fluctuates around zero in cold months and an increase in air temperature has important impact on precipitation phase. Cold boreal and arctic zones are also sensitive to changes in precipitation phase but in contrast with mild climate zones, this process influences precipitation especially in summer, because air temperature in all other seasons is usually well below zero. Generally, it is pointless to analyse any changes in precipitation phase in regions with warm oceanic type of climate where the proportion of solid precipitation is very low (e.g. British Isles and France).

Nevertheless, mountainous areas are the most endangered, because worse availability of water related to reduced snow cover extent and depth together with decreasing mass of glaciers may have negative impacts on availability of water. Barnett, Adam, Lettenmaier (2005) claims that nearly one sixth of world population (e.g. in northern China, northwestern India, western America, Alps) may be negatively influenced by reduced snow extent and glacier mass.

Because of air temperature growth and consequent decrease of solid precipitation, the snow cover extent and depth is reduced. Shrinking of snow cover is particularly important in mild and boreal zones with nival and nival-pluvial runoff regime, where melting of snow cover constitutes important part of the spring runoff. Decrease of snow cover has two major results. First, the combination of increased proportion of liquid precipitation and earlier onset of snowmelt leads to the strengthening and shift of the peak runoff and higher probability of spring floods (e.g. Middelkoop et al. 2001). Takala et al. (2009) demonstrated an earlier onset of melting of spring snow cover for Eurasia during 1979 and 2007, which was accompanied by the shift of the highest runoff to winter or earlier spring in some areas (Barnett, Adam, Lettenmaier 2005; Tan, Adam, Lettenmaier 2011). Secondly, the reduced extent and depth of snow cover negatively influence the 
availability of water in summer. This process is closely related to ground water, which serves as a water reserve in summer. Ground water is mainly replenished during spring months, when water from melting snow slowly infiltrates and refills it. Liquid precipitation flows away from the land, thereafter causing less water stored in snow. Thus, higher proportion of liquid precipitation and consequent reduced extent and depth of snow cover lead to insufficient refill of groundwater. These processes may lessen ground water reserves and then worsen availability of ground water in summer months. Also, linkage to society is clearly evident, as water may be shortened to population, agriculture and hydropower. Another effect of decreasing S/P is on winter tourism (Elsasser, Bürki 2002): because of higher air temperature, the area with snow depth and extent sufficient for winter sports is being reduced, especially in lower elevations. Due to this fact, running and maintenance of ski centres in lower altitudes is probably being more expensive and complicated then nowadays.

Changes in the precipitation phase are studied by several methods, which are however limited by the availability of data. Unfortunately, data about precipitation phase are usually not available for every precipitation record, thus approximation of precipitation phase is necessary. Three methods are generally used in relevant studies. One method is based on threshold temperature, which separates solid and liquid precipitation (Fuchs et al. 2000; Zanotti et al. 2004; L'Hote et al. 2005; Dai 2008; Ye, Cohen, Rawlins 2013). Precipitation observed above (below) threshold temperature is considered as liquid (solid). The value of threshold temperature separating liquid and solid precipitation mostly ranges from -1.0 to $+2.5^{\circ} \mathrm{C}$ (e.g. Dai 2008; Feiccabrino, Lundberg 2008; Jennings et al. 2018), depending on location, air temperature variable (daily maximum, minimum), relative humidity, etc. Two threshold temperatures may be also applied on data: one separates liquid from mixed precipitation, while the other mixed from solid precipitation. Mixed precipitation may be divided into liquid and solid precipitation or may be analysed as a separate category. Another method determines precipitation phase by snowfall occurrence - if snowfall is recorded, daily precipitation total is considered as solid, otherwise it is liquid (e.g. Huntington et al. 2004; Knowles, Dettinger, Cayan 2006; Feng, Hu 2007). The third method, which is described in detail here, uses SYNOP report and daily precipitation totals. Occurrence and number of specific codes in SYNOP report determine phase of daily precipitation total as solid, combined (representing mixed precipitation), or liquid (Dai 2008; Ye, Cohen, Rawlins 2013).

In this paper, changes in precipitation phase as well as in precipitation totals are analysed between November and April in 1983-2018 in Czechia. For this purpose, stations where both SYNOP reports and data on daily precipitation totals are available are utilized in this study. Trends of $\mathrm{S} / \mathrm{P}$ ratio, solid, combined, liquid and precipitation totals are calculated there. 


\section{Data}

Data of ten stations in Czechia (Fig. 1) between 1983 and 2018 are used in this study. The SYNOP report and daily total precipitation are available for every day from November to April there. SYNOP reports are recorded every hour (so 24 SYNOP reports are available every day), however, the time interval of SYNOP reports was extended to three hours in the 1980's (i.e., 8 SYNOP reports are available every day) at some stations. Furthermore, manual observations of some weather characteristics during night (e.g. precipitation phase, total cloud cover) were reduced or replaced by instruments at seven stations approximately between 2000 and 2010 . The quality of SYNOP reports during night is probably less accurate afterwards since the instruments are less precise than observers and observations of some weather characteristics are lacking completely. The automatic observation is not the case of three stations - Praha, Ruzyně; Brno, Tuřany and Ostrava, Mošnov.

The SYNOP report contains information about actual weather at the station. For our purposes, the important part of the report is 'weather condition' where codes describing precipitation phase (liquid, mixed, or solid) at the time of observation or during the last observation period (one or three hours) are recorded. All codes that are used in this study and the corresponding precipitation phase (solid, mixed

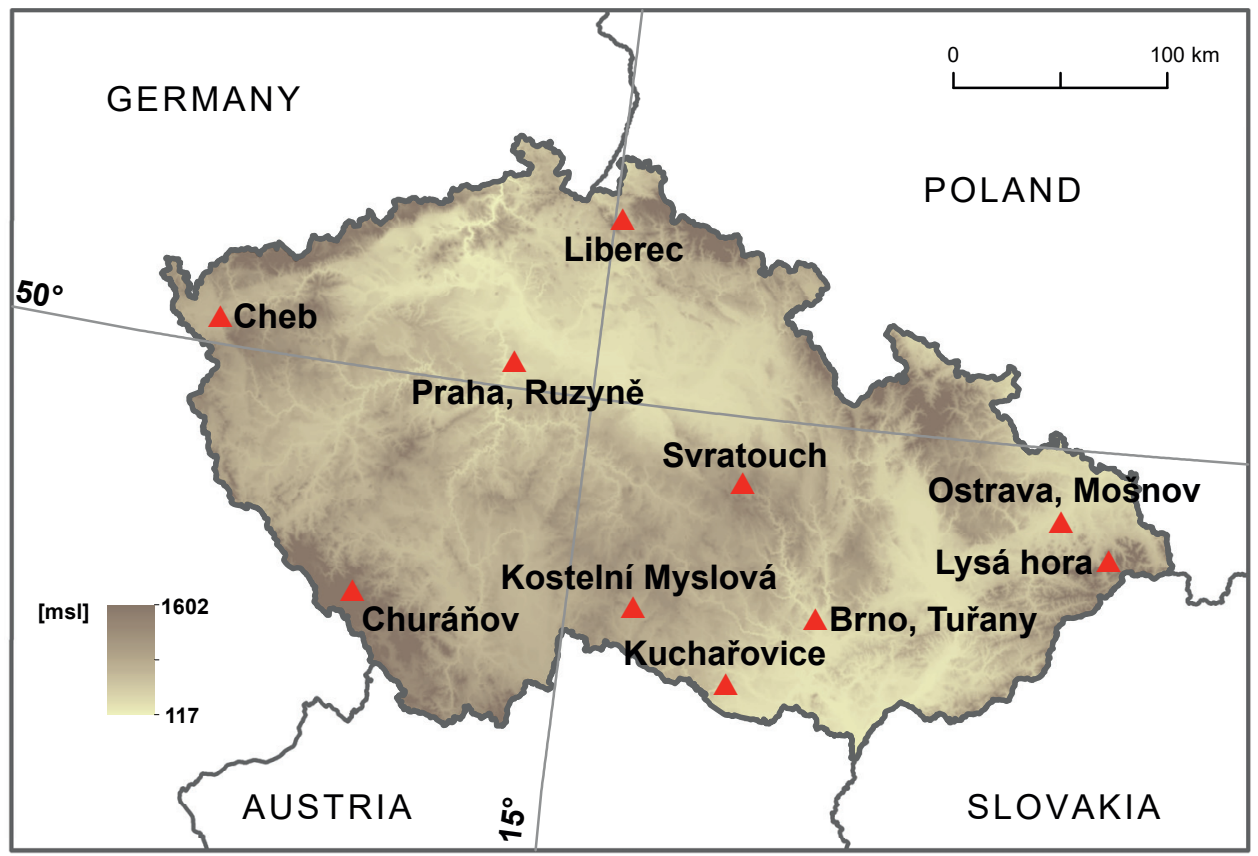

Fig. 1 - Location of stations in Czechia 
Tab. 1 - List of "weather condition" codes in SYNOP report used in this study, their descriptions and occurrence (\%) in SYNOP reports over all Czech stations between November and April in 1983-2018

\begin{tabular}{|c|c|c|c|c|}
\hline \multirow{2}{*}{$\begin{array}{l}\text { Precipitation } \\
\text { phase }\end{array}$} & \multirow{2}{*}{$\begin{array}{l}\text { Code } \\
21\end{array}$} & \multirow{2}{*}{$\begin{array}{l}\text { Weather condition } \\
\text { Rain (in the last hour) }\end{array}$} & \multicolumn{2}{|c|}{$\begin{array}{l}\text { Proportion (\%) } \\
\text { in SYNOP reports }\end{array}$} \\
\hline & & & 8.95 & 60.90 \\
\hline & 24 & Freezing rain or drizzle (in the last hour) & 0.63 & \\
\hline & 25 & Rain showers (in the last hour) & 5.33 & \\
\hline & 29 & Thunderstorm (with or without precipitation) & 1.15 & \\
\hline & $50-55$ & Drizzle & 4.08 & \\
\hline & $56-57$ & Freezing drizzle & 0.88 & \\
\hline & $58-59$ & Drizzle and rain & 0.27 & \\
\hline & $60-65$ & Rain (not in showers) & 31.84 & \\
\hline & $66-67$ & Freezing rain (not in showers) & 0.69 & \\
\hline & $80-82$ & Rain showers & 5.39 & \\
\hline & $91-92$ & $\begin{array}{l}\text { Rain (thunderstorm in last hour, precipitation at the } \\
\text { observation time) }\end{array}$ & 0.37 & \\
\hline & 95,97 & Thunderstorm with precipitation & 1.32 & \\
\hline \multirow[t]{10}{*}{ SOLID } & 22 & Snow (in the last hour) & 3.41 & 36.63 \\
\hline & 26 & Snow shower or snow shower with rain (in the last hour) & 2.09 & \\
\hline & $70-75$ & Snow & 25.44 & \\
\hline & 76 & Diamond dust & 0.07 & \\
\hline & 77 & Snow grains & 0.66 & \\
\hline & 78 & Snow crystals & 0.19 & \\
\hline & 79 & Ice pellets & 0.05 & \\
\hline & $85-86$ & Snow shower & 4.50 & \\
\hline & $87-88$ & Snow/ice pellet showers & 0.20 & \\
\hline & $93-94$ & $\begin{array}{l}\text { Snow or rain/snow mix (thunderstorm in last hour, } \\
\text { precipitation at the observation time) }\end{array}$ & 0.02 & \\
\hline \multirow[t]{3}{*}{ MIXED } & 23 & Rain and snow (in the last hour) & 0.98 & 2.47 \\
\hline & $68-69$ & Rain and snow or drizzle and snow & 1.34 & \\
\hline & $83-84$ & Rain and snow showers & 0.16 & \\
\hline
\end{tabular}

or liquid) are displayed in Table 1 . The percentage of occurrence of single codes as well as the precipitation phases in SYNOP reports reveals that the liquid codes occur more frequently than the solid and mixed precipitation codes (Table 1). The most often recorded weather codes are 'rain' and 'snow', while the incidence of for example 'diamond dust' or 'ice pellets' is rare.

We note that the categorisation of some codes into a single precipitation phase may be disputable: e.g. freezing rain occurs at air and/or surface temperatures below zero, but because rain freezes at the moment it reaches the surface, it belongs to liquid precipitation. Code 26 ("snow shower or snow shower with rain [in the last hour]") is included into solid precipitation although it may contain both solid and mixed precipitation phase. Nevertheless, we suppose that solid precipitation 
has a higher proportion in this category because there is an additional specific code for rain and snow shower (code 23). Even more problematic are codes describing the occurrence of thunderstorm $(29,93-95$, and 97). Codes 29 ("thunderstorm with or without precipitation") and 95, 97 ("thunderstorm with precipitation") do not determine specific precipitation phase. Yet, all these codes are taken as liquid precipitation, because the majority of thunderstorms in the cold half year, which is analysed here, occur in autumn and spring when liquid precipitation prevails. Since the majority of thunderstorms in Czechia are accompanied with precipitation, code 29 is included among the codes indicating the occurrence of precipitation although it includes the possibility of no precipitation being detected at the observing site. Codes 93 and 94 ("snow or rain/snow mix [thunderstorm in last hour, precipitation at the observation time]") indicate both solid and mixed precipitation forms. We decided to assign them to solid precipitation; this has negligible impact only, because the occurrence of these codes is very low $(0.02 \%)$. All the codes just discussed do not determine a precipitation phase uniquely, thereby introducing uncertainty into its determination. However, due to the fairly low occurrence of these codes, we do not expect this may bias results of our study.

When only solid or only liquid codes are recorded on a day, that particular day is categorised as a day with solid or liquid precipitation, respectively. The day with combined precipitation is defined as a day when either at least one code for mixed precipitation is recorded or both liquid and solid codes are recorded. Each day with precipitation is thus assigned to just one precipitation phase. Nevertheless, there are some cases when precipitation phase cannot be identified because weather condition codes describing precipitation phase are not recorded. We assume that this may be caused by the switch from manual to automatic observation of precipitation types during night at the majority of stations. Even though the instrument is able to record seven precipitation types (snow, rain, drizzle, mixed rain/snow, freezing rain, freezing drizzle and ice pellets), its reliability is certainly lower than manual observation and thus also affecting quality of SYNOP reports where information on precipitation phase during night may be inaccurate or even lacking. Daily precipitation totals without assigned precipitation phase are not included in calculation of trends and proportions of individual precipitation phases. We use terms 'solid', 'combined,' and 'liquid' precipitation for total precipitation in days with solid, combined, and liquid precipitation for the sake of simplicity.

We define the ratio of solid to total precipitation, S/P, as a percentage of solid (S) vs. total (solid plus liquid plus combined precipitation; $\mathrm{P}$ ) precipitation. The analysed cold half-years are denoted by the year when they end, that is, season November 1996 - April 1997 is denoted as 1997.

Long-term trends of S/P $\left(\% \cdot\right.$ year $\left.^{-1}\right)$ and of total, solid, combined, and liquid precipitation (all in $\mathrm{mm} \cdot \mathrm{year}^{-1}$ ) are determined by simple linear regression. Their statistical significance is tested by $\mathrm{t}$-test at the $5 \%$ level. 


\section{Results}

Figure 2 confirms that the proportion of solid (liquid) precipitation increases (decreases) with altitude, as expected. At mountain stations (Lysá hora 1,322 $\mathrm{m}$ a.s.l.; Churáńov 1,118 $\mathrm{m}$ a.s.l.), the average S/P between November and April is roughly between $40-70 \%$, while it decreases to $15-25 \%$ at stations below $500 \mathrm{~m}$ a.s.l. The differences in S/P between Lysá hora and Churáňov (average S/P is 62 and 44\%, respectively) may be caused by different station elevations, because Lysá hora is situated higher and has colder climate than Churáňov (average air temperatures between November and April at Lysá hora and Churáňov in the period analysed are $-2.5^{\circ} \mathrm{C}$ and $-0.6^{\circ} \mathrm{C}$, respectively). Another explanation lies in the different surrounding landforms around stations: Lysá hora is situated on a rather isolated mountain peak, overtopping the surrounding terrain by several hundreds of meters, whereas Churáňov is located on a flat plateau where larger radiation impact of ground on adjacent air also leads to its stronger heating, resulting in higher sensitivity to increasing air temperature and thus more combined and liquid precipitation.

The highest proportion of liquid precipitation is observed at low elevations, where it is usually between $40-60 \%$. The proportion of combined precipitation is quite similar across all stations (20-40\%), but stations with its highest proportion

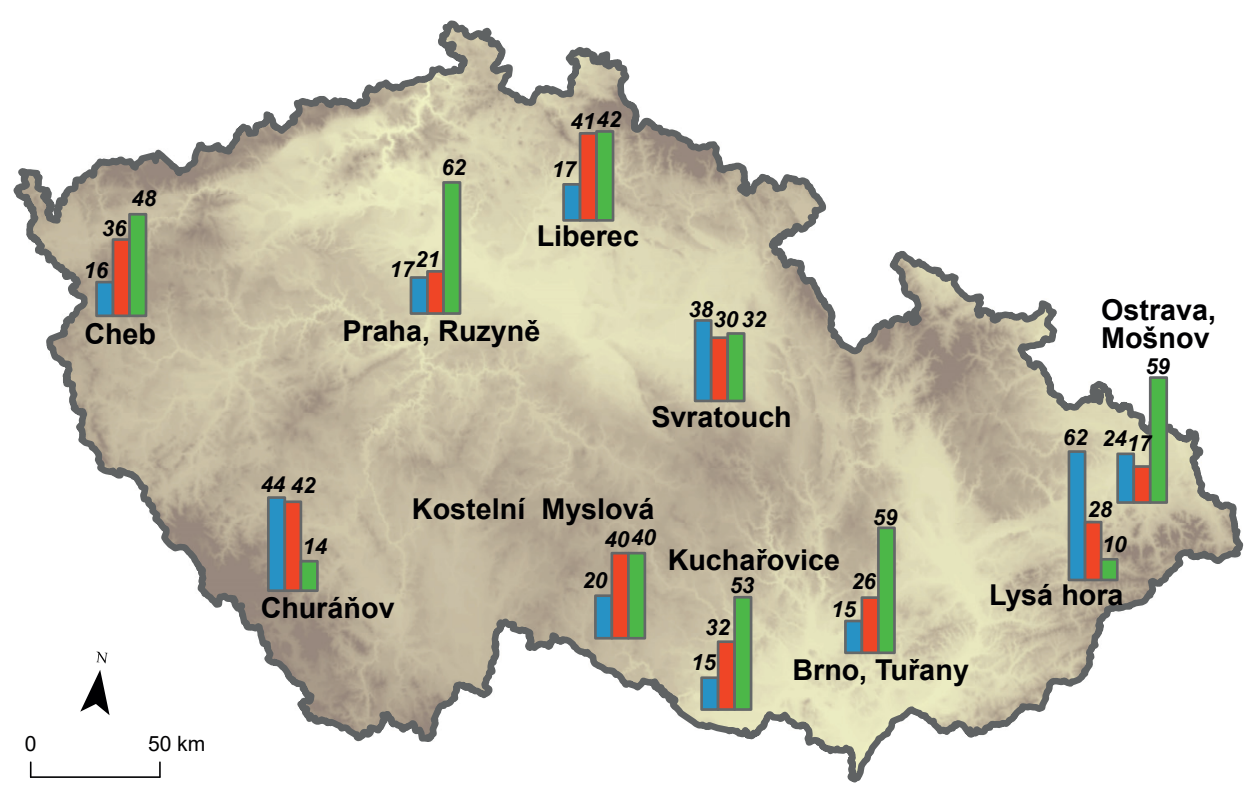

Fig. 2 - Proportion (in \%) of solid (blue), combined (red) and liquid (green) precipitation for November-April, 1983-2018 
Tab. 2 - List of stations, their elevation, and trends of solid, combined, liquid, and total precipitation $\left(\mathrm{mm} \cdot\right.$ year $\left.^{-1}\right)$, and trend of S/P $\left(\% \cdot\right.$ year $\left.^{-1}\right)$ in 1983-2018. The last row contains trends for the average values over all stations. Values statistically significant at the $5 \%$ are denoted by asterisk.

\begin{tabular}{lcccccc}
\hline Station & Elevation (m a.s.l.) & Solid & Combined & Liquid & Total & S/P \\
\hline Brno, Tuřany & 237 & -0.38 & 0.13 & 0.10 & -0.15 & $-0.24^{*}$ \\
Ostrava, Mošnov & 257 & $-0.83^{*}$ & -0.19 & 0.26 & -0.75 & $-0.34^{*}$ \\
Kuchařovice & 334 & $-0.93^{*}$ & $1.71^{*}$ & -0.60 & 0.18 & $-0.66^{*}$ \\
Praha, Ruzyně & 380 & $-0.52^{*}$ & -0.04 & 0.39 & -0.17 & $-0.40^{*}$ \\
Liberec & 405 & $-1.79^{*}$ & $2.69^{*}$ & $-1.78^{*}$ & -0.88 & $-0.52^{*}$ \\
Cheb & 483 & $-1.14^{*}$ & $2.35^{*}$ & -0.56 & 0.65 & $-0.56^{*}$ \\
Kostelní Myslová & 569 & $-1.44^{*}$ & $1.94^{*}$ & -0.61 & -0.11 & $-0.66^{*}$ \\
Suratouch & 733 & $-2.09^{*}$ & -0.25 & -0.35 & $-2.69^{*}$ & $-0.47^{*}$ \\
Churáňov & 1,118 & $-4.92^{*}$ & $2.61^{*}$ & -0.29 & -2.60 & $-0.84^{*}$ \\
Lysá hora & 1,322 & $-2.64^{*}$ & $4.02^{*}$ & 0.56 & 1.94 & $-0.77^{*}$ \\
\hline All stations & - & $-1.66^{*}$ & $1.50^{*}$ & -0.26 & -0.42 & $-0.60^{*}$ \\
\hline
\end{tabular}

are located between 500 and 1,100 m a.s.l (Churáňov, Liberec and Kostelní Myslová). However, it should be emphasized that the proportion of combined precipitation (average over the Czech stations is $33 \%$ between November and April) is overestimated due to the methodology of determination of the precipitation phase. The reason is that only one SYNOP report (out of four or eight) on a day with combined precipitation is enough for all daily precipitation to be considered as combined, although only liquid or only solid precipitation might be recorded at

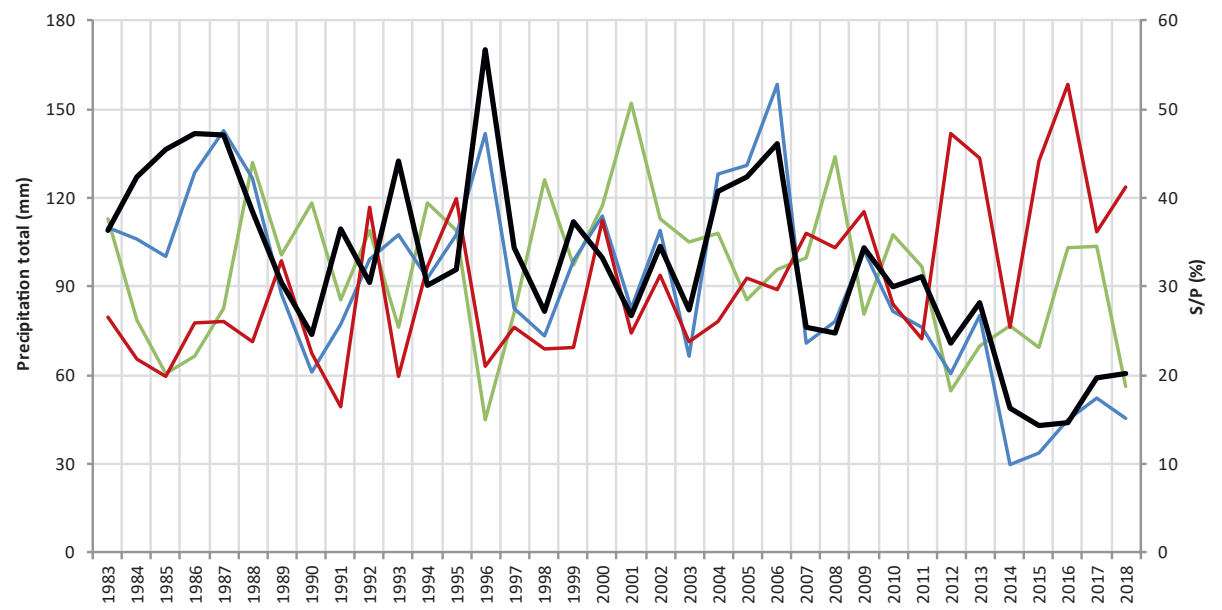

Fig. 3 - Time series of mean S/P (black line, right axis), solid (blue), combined (red) and liquid (green) precipitation (left axis) for all Czech stations together for period November-April between 1983 and 2018 


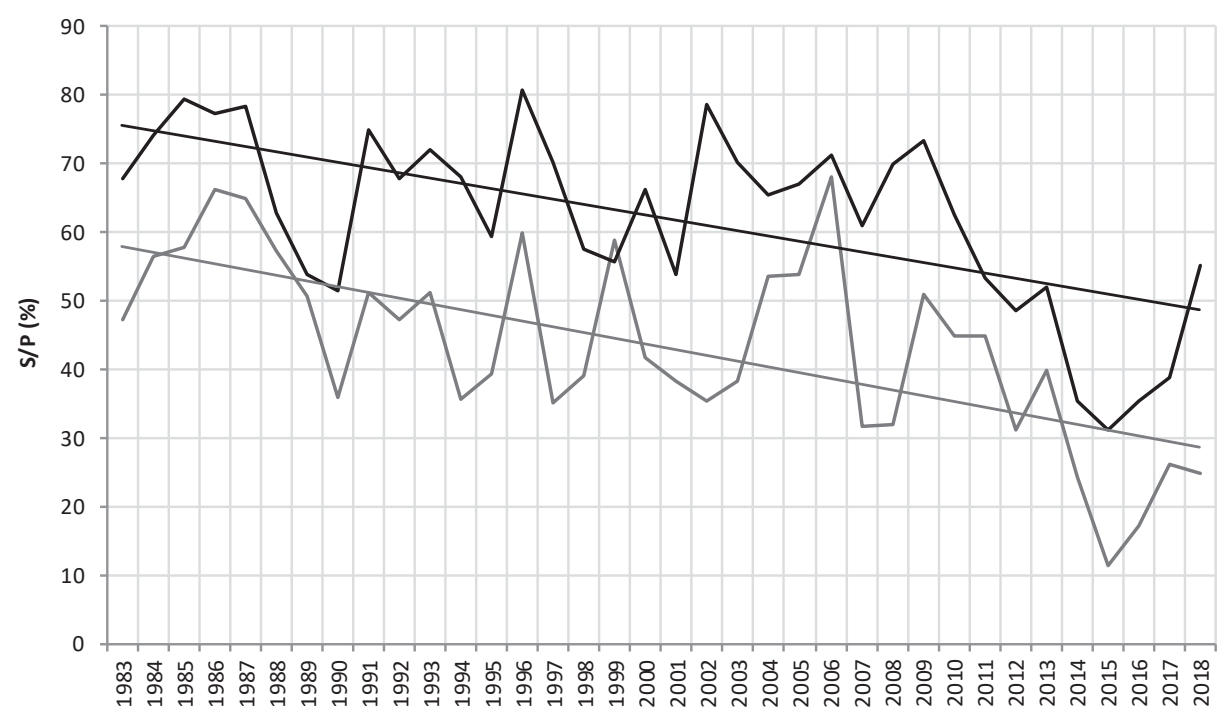

Fig. 4 - Time series of S/P (\%) and linear regression trend lines at Lysá hora (dark grey) and Churáňov (light grey) stations for period November-April between 1983 and 2018

other observation times that day. Similarly, a day when liquid and solid precipitation is reported separately is considered as a day with combined precipitation even though no mixed precipitation actually occurs.

The average of the Czech stations has a negative significant trend of S/P (Table 2; $-0.60 \% \cdot$ year $\left.^{-1}\right)$, which is caused by significant decrease in solid precipitation $\left(-1.66 \mathrm{~mm} \cdot\right.$ year $\left.^{-1}\right)$ and increase in combined precipitation $\left(1.50 \mathrm{~mm} \cdot\right.$ year $\left.^{-1}\right)$. Slight decrease in both liquid and total precipitation is statistically insignificant. Figure 3 shows that the strong decline of S/P started in 2007 and continued afterwards. The trend of S/P between 1983 and 2006 was only $-0.18 \% \cdot$ year $^{-1}$, being insignificant. Negative trend of solid precipitation after 2007 is accompanied by a strong increase in combined precipitation, suggesting the shift of precipitation phase from solid to combined.

Table 2 shows that S/P significantly declines at all stations. The reason is the same as for the average over all stations - decrease in solid precipitation (significant at all stations but Brno, Turany), mostly increase in combined precipitation and varied trends of liquid precipitation. Trends of precipitation totals are mostly negative and insignificant (the exception is Svratouch with significantly negative trend). The decrease in solid precipitation becomes generally stronger with altitude (the stations located above $400 \mathrm{~m}$ a.s.l have trends between approximately -1 and $-5 \mathrm{~mm} \cdot$ year $^{-1}$ ). Slightly negative trends of liquid precipitation are caused by its decrease after roughly 2005-2007. 


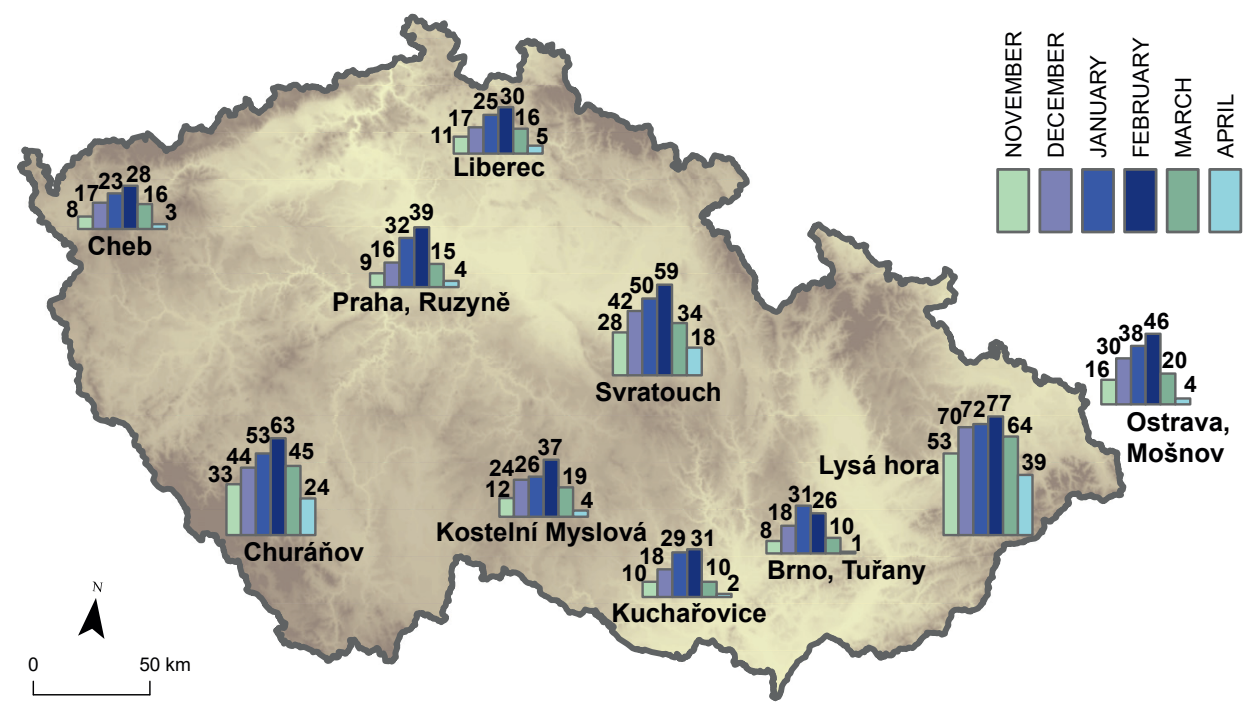

Fig. 5 - Average proportion of solid precipitation on precipitation totals (S/P; in \%) for single months between November-April between 1983 and 2018

The most negative S/P trends are located at mountain stations Churáňov and Lysá hora (Fig. 4), both having the strongest decreases in solid precipitation of all stations, accompanied by a significantly positive trend of combined precipitation. Opposite trends of precipitation totals may be partly explained by geographical locations of stations, because precipitation at Lysá hora is more frequently caused by cyclones originated in the Mediterranean or near the Alps whereas precipitation is carried mainly by westerly-southwesterly flow from the Atlantic Ocean at Churáňov.

Tab. 3 - Solid, combined, and liquid precipitation proportion (\%) and its trends $\left(\mathrm{mm} \cdot \mathrm{year}^{-1}\right)$ together with total precipitation trends $\left(\mathrm{mm} \cdot\right.$ year $\left.^{-1}\right)$ and S/P trends $\left(\% \cdot\right.$ year $\left.^{-1}\right)$ in 1983-2018 for individual months over all stations. Values statistically significant at the $5 \%$ are denoted by asterisk.

\begin{tabular}{lcccccccc}
\hline & \multicolumn{2}{c}{ Solid } & \multicolumn{2}{c}{ Combined } & \multicolumn{2}{c}{ Liquid } & Total & S/P \\
\hline & Proportion & Trend & Proportion & Trend & Proportion & Trend & Trend & Trend \\
\hline November & 23 & -1.70 & 31 & $2.83^{*}$ & 46 & -0.64 & 0.49 & -0.35 \\
December & 36 & $-3.30^{*}$ & 37 & 0.95 & 27 & $-2.62^{*}$ & $-4.97^{*}$ & $-0.48^{*}$ \\
January & 43 & -2.33 & 36 & $4.89^{*}$ & 21 & 0.53 & 3.09 & $-0.63^{*}$ \\
February & 51 & $-4.50^{*}$ & 31 & 1.86 & 18 & 1.20 & -1.45 & $-1.05^{*}$ \\
March & 32 & $-2.66^{*}$ & 35 & $2.92^{*}$ & 33 & 0.02 & 0.28 & $-0.56^{*}$ \\
April & 15 & $-2.10^{*}$ & 27 & 1.43 & 58 & -1.25 & -1.92 & $-0.47^{*}$ \\
\hline
\end{tabular}


$\mathrm{S} / \mathrm{P}$ is highest in February and lowest in April at all stations, apart from Brno, Tuřany (Fig. 5). Average S/P over all stations is $51 \%$ in February, $43 \%$ in January and $36 \%$ in December, while it is only $15 \%$ in April (Table 3). Even at stations at low elevations, $\mathrm{S} / \mathrm{P}$ is always higher than $26 \%$ in February, while $\mathrm{S} / \mathrm{P}$ is highest at Lysá hora (77\%), the uppermost station in this study. Figure 5 again demonstrates the negative influence of local climate on $\mathrm{S} / \mathrm{P}$ at Churáňov as its monthly $\mathrm{S} / \mathrm{P}$ values are close to those at Svratouch, which lies nearly $400 \mathrm{~m}$ below Churáňov.

Mean S/P over all stations significantly (apart from November) decreases in all months. The strongest negative $\mathrm{S} / \mathrm{P}$ trend is detected in February $\left(-1.05 \% \cdot \mathrm{year}^{-1}\right)$, followed by January $\left(-0.63 \% \cdot\right.$ year $\left.^{-1}\right)$ and March $\left(-0.56 \% \cdot\right.$ year $\left.^{-1}\right)$. Negative trends of $\mathrm{S} / \mathrm{P}$ in all months are accompanied by decrease in solid precipitation and increase in combined precipitation. Trends in liquid and total precipitation are various and insignificant with the exception of December when both have strong and significant decrease.

\section{Discussion}

In this study, we examine long-term changes in precipitation phase in Czechia. The $\mathrm{S} / \mathrm{P}$ ratio significantly declines at all stations, while it is accompanied by decrease in solid precipitation, increase in combined and varied trends of liquid precipitation at majority of them. However, magnitudes of trends are influenced by the quality of data as well as used methods. It is well-known fact that linear regression is highly affected by extreme or outlying values if they occur near the start or end of the studied period. Fortunately, the decrease of S/P after 2007 is prominent and clearly visible in Figure 3, which supports our results and indicates that it is not a result of a single (or a few of) outlying value(s). We are also aware of the fact that changes from manual to automatic observations of precipitation phase during night (Sec. 2) between 2000 and 2010 might have influenced the results. Although automatic instruments are able to distinguish seven types of precipitation phases, they cannot fully replace manual observations. Three stations (Praha, Ruzyně; Brno, Tuřany, and Ostrava, Mošnov) where the manual observation of precipitation phase during night is preserved, have in comparison with other stations different trends in combined (weaker, close to zero trends) and liquid (slightly positive trends) precipitation. On the other hand, the behaviour of solid precipitation is the same at all stations. Thus, the influence of automatic observations during night on magnitude of trends is speculative and it might be only coincidence that the three aforementioned stations have slightly different trends in some precipitation phases.

Although there are several approaches to study changes in S/P (Sec. 1), the determination of precipitation phase with the use of SYNOP reports is probably the most accurate, because it is based on real observations, whereas the other 


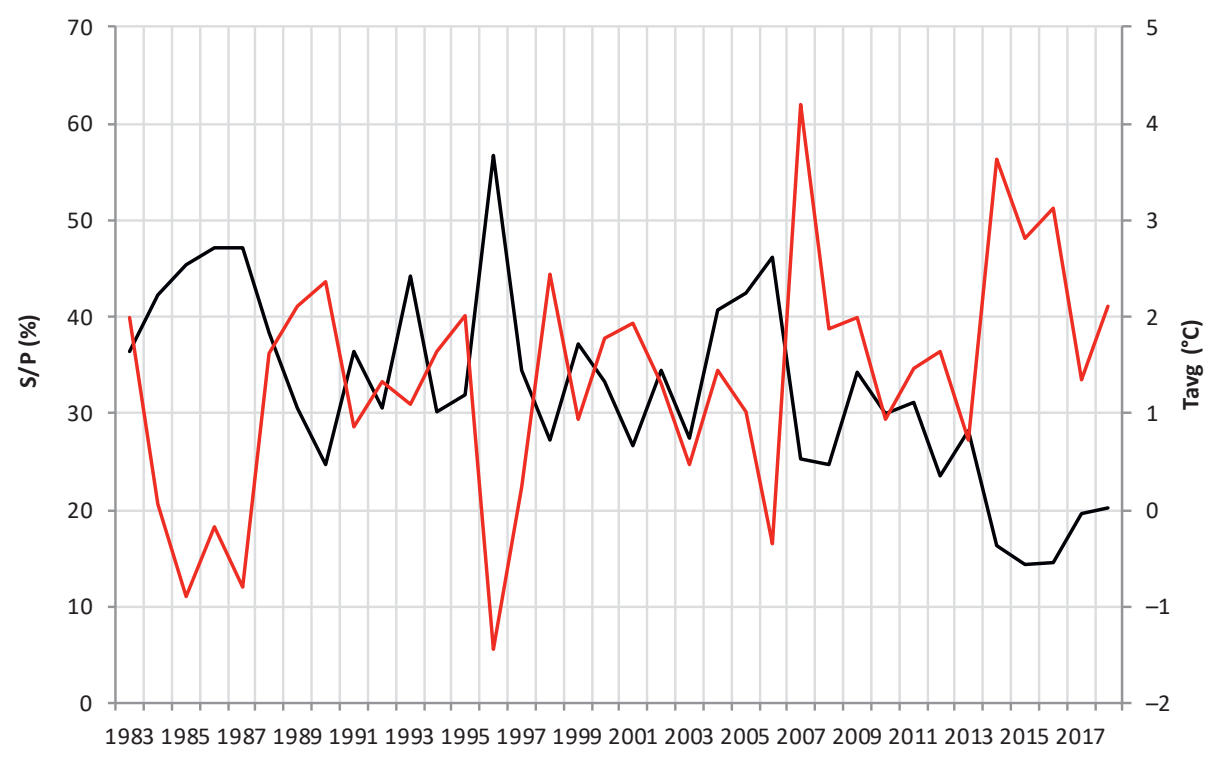

Fig. 6 - Time series of mean S/P (black line, left axis) and average temperature Tavg (red line, right axis) for all Czech stations together for period November-April between 1983 and 2018

approaches are oversimplified (e.g. identification of precipitation phase by observation of snowfall) or rely on derived values (e.g. threshold temperature). Nevertheless, presented results are necessarily only approximations of the real change in the S/P since we do not know precipitation phase of every single $0.1 \mathrm{~mm}$ precipitation total. Our method also leads to an overestimation of combined precipitation. Despite these disadvantages, we consider determining of precipitation phase with use of SYNOP reports as the most appropriate.

Our results are hard to compare with other studies, because we are not aware of any study describing long-term changes in precipitation phase in Czechia. The few articles analysing changes in S/P in Europe are all focused on either a single station or/and different climate conditions. Twardosz et al. (2012) found significant increase in precipitation total but almost no change in solid precipitation in Krakow between 1863 and 2008. In Finland, Irannezhad et al. (2017) detected negative trend of S/P at one out of three analysed stations between 1959 and 2008. Other studies analyse changes in S/P only at high altitude stations in the Alps (Schöner, Auer, Böhm 2009; Marty, Meister 2012) and it is not possible to compare them with our results.

There are several factors, which influence $\mathrm{S} / \mathrm{P}$ ratio, but air temperature seems to be the most important (Ye, Cohen, Rawlins 2013). We also proved that temperature is crucial factor, because the Pearson correlation between the series of S/P 
and temperature (both between November and April) averaged over all Czech stations is -0.79 . The coincidence between temperature and $\mathrm{S} / \mathrm{P}$ is particularly evident after 2013 (Fig. 6) when the increase of temperature is accompanied with rapidly falling S/P. Correlations between temperature and S/P at individual stations range from -0.58 (Praha, Ruzyně) to -0.80 (Brno, Tuřany). Therefore, since the relationship between $\mathrm{S} / \mathrm{P}$ and temperature is rather strong, the negative trend of S/P may be explained by growing air temperature. According to Brázdil et al. (2009), monthly air temperature trend in Czechia (1961-2005) between December and April is positive; only in November it is close to zero. November is also the month with the least negative trend of S/P (Table 3). Increase of air temperature certainly causes negative trend of $\mathrm{S} / \mathrm{P}$, because higher air temperature reduces total solid precipitation and consequently the S/P.

\section{Conclusions}

We analyse changes in the precipitation phase in Czechia between November and April from 1983 to 2018 at ten stations. At every station, the occurrence of specific codes in SYNOP reports determines the precipitation phase of daily precipitation totals as solid, combined, or liquid. Trends of the precipitation phases and of the precipitation totals are calculated by linear regression. Furthermore, the trend of $\mathrm{S} / \mathrm{P}$ (solid to total precipitation ratio) gives us information about changing proportion of solid to total precipitation. S/P significantly declines at all Czech stations, average value of the trend over all stations being $-0.60 \% \cdot$ year $^{-1}$. This trend is accompanied by decrease in solid precipitation $\left(-1.66 \mathrm{~mm} \cdot\right.$ year $\left.^{-1}\right)$, increase in combined precipitation $\left(+1.50 \mathrm{~mm} \cdot\right.$ year $\left.^{-1}\right)$ and slightly negative trend of liquid precipitation $\left(-0.26 \mathrm{~mm} \cdot\right.$ year $\left.^{-1}\right)$. At all stations (with the exception of Brno, Tuřany), solid precipitation significantly decreases, which is compensated by increases in combined precipitation at the majority of them. This indicates a shift of precipitation phase from solid to combined. Trends of liquid precipitation are varied and mostly insignificant. In the case of individual months, the highest decrease in S/P is in February $\left(-1.05 \% \cdot\right.$ year $\left.^{-1}\right)$ and January $\left(-0.63 \% \cdot\right.$ year $\left.^{-1}\right)$. In a mild climate zone, the logical and simple explanation of decreasing $\mathrm{S} / \mathrm{P}$ exists: the observed increase in air temperature leads to a more frequent occurrence of combined (mixed) and liquid precipitation, whereas the occurrence and proportion of solid precipitation are decreasing. In the next decades, climate projections for Czechia expect increases of air temperature in all seasons including winter, while the total precipitation is expected to decrease in winter. Precipitation totals will probably increase during autumn and spring (Pretel et al. 2011). Because the air temperature is the main factor controlling the precipitation phase, we may expect a further decrease in $\mathrm{S} / \mathrm{P}$ in the following decades. 


\section{References}

BARNETT, T.P., ADAM, J.C., LETTENMAIER, D.P. (2005): Potential impacts of a warming climate on water availability in snow-dominated regions. Nature, 438, 303-309.

BRÁZDIL, R., CHROMÁ, K., DOBROVOLNÝ, P., TOLASZ, R. (2009): Climate fluctuations in the Czech Republic during the period 1961-2005. International Journal of Climatology, 29, 223-242.

DAI, A. (2008): Temperature and pressure dependence of the rain-snow phase transition over land and ocean. Geophysical Research Letters, 35.

ELSASSER, H., BÜRKI, R. (2002): Climate change as a threat to tourism in the Alps. Climate Research, 20, 253-257.

FEICCABRINO, J., LUNDBERG, A. (2008): Precipitation phase discrimination in Sweden. $65^{\text {th }}$ Eastern snow conference 28. 5. - 30. 5. 2008. Fairlee, USA, 239-254.

FENG, S., HU, Q. (2007): Changes in winter snowfall/precipitation ratio in the contiguous United States. Journal of Geophysical Resssearch, 112.

FUCHS, T., RAPP, J., RUBEL, F., RUDOLF, B. (2000): Correction of synoptic precipitation observations due to systematic measuring errors with special regard to precipitation phases. Physics and Chemistry of the Earth, 26, 689-693.

HUNTINGTON, T.G., HODGKINS, G.A., KEIM, B.D., DUDLEY, R.W. (2004): Changes in the proportion of precipitation occurring as snow in New England (1949-2000). Journal of Climate, 17, 2626-2636.

IRANNEZHAD, M., RONKANEN, A. K., KIANI, S., CHEN, D., KLøVE, B. (2017): Long-term variability and trends in annual snowfall/total precipitation ratio in Finland and the role of atmospheric circulation patterns. Cold Regions Science and Technology, 143, 23-31.

JENNINGS, K.S., WINCHELL, T.S., LIVNEH, B., MOLOTCH, N.P. (2018): Spatial variation of the rain-snow temperature threshold across the Northern Hemisphere. Nature Communications, 9.

KNOWLES, N., DETTINGER, M.D., CAYAN, D.R. (2006): Trends in snowfall versus rainfall in the Western United States. Journal of Climate, 19, 4545-4559.

L'HÔTE, Y., CHEVALLIER, P., COUDRAIN, A., LEJEUNE, Y., ETCHEVERS, P. (2005): Relationship between precipitation phase and air temperature: comparison between the Bolivian Andes and the Swiss Alps. Hydrological Sciences Journal, 50, 989-997.

MARTY, CH., MEISTER, R. (2012): Long-term snow and weather observations at Weissfluhjoch and its relation to other high-altitude observatories in the Alps. Theoretical and Applied Climatology, 110, 573-583.

MIDDELKOOP, H., DAAMEN, K., GELLENS, D., GRABS, W., KWADIJK, J.C., LANG, H., WILKE, K. (2001): Impact of climate change on hydrological regimes and water resources management in the Rhine basin. Climatic Change, 49, 105-128.

PRETEL, J., METELKA, L., NOVICKÝ, O., DAŇHELKA, J., ROŽNOVSKÝ, J., JANOUŠ, D. (2011): Zpřesnění dosavadních odhadů dopadů klimatické změny v sektorech vodního hospodářství, zemědělství a lesnictví a návrhy adaptačních opatření. Technické shrnutí výsledků řešení projektu VaV SP/1a6/108/07 v letech 2007-2011. ČHÚ, UK, VÚV, CVGZ AV ČR, VÚRV, Praha.

SCHÖNER, W., AUER, I., BÖHM, R. (2009): Long term trend of snow depth at Sonnblick (Austrian Alps) and its relation to climate change. Hydrological Processes, 23, 1052-1063.

TAKALA, M., PULLIAINEN, J., METSÄMÄKI, S.J., KOSKINEN, J.T. (2009): Detection of snowmelt using spaceborne microwave radiometer data in Eurasia from 1979 to 2007. Transactions on Geoscience and Remote Sensing, 47, 2996-3007. 
TAN, A., ADAM, J.C., LETTENMAIER, D.P. (2011): Change in spring snowmelt timing in Eurasian Arctic rivers. Journal of Geophysical Research - Atmospheres, 116.

TWARDOSZ, R., ŁUPIKASZA, E., NIEDŹWIEDŹ, T., WALANUS, A. (2012): Long-term variability of occurrence of precipitation forms in winter in Kraków, Poland. Climatic Change, 113, 623-638.

YE, H., COHEN, J., RAWLINS, M. (2013): Discrimination of solid from liquid precipitation over Northern Eurasia using surface atmospheric conditions. Journal of Climate, 14, 1345-1355.

ZANOTTI, F., ENDRIZZI, S., BERTOLDI, G., RIGON, R. (2004): The GEOTOP snow module. Hydrological Processes, 18, 3667-3679.

\section{ACKNOWLEDGMENTS}

This study was supported by the Czech Science Foundation, project 16-04676S, Martin Hynčica was supported by the Grant Agency of Charles University, project GAUK426216. 